\title{
ODNOS DOŽIVLJAJA SAGORIJEVANJA U RADU, EMOCIONALNE KOMPETENCIJE I OBILJEŽJA POSLA ODGAJATELJICA PREDŠKOLSKE DJECE
}

\author{
Dijana Frančešević \\ Dječji vrtić „Kustošija“, Zagreb \\ Kindergarten „Kustošija“, Zagreb \\ JošKo SINDIK \\ Institut za antropologiju, Zagreb \\ Institute for Anthropological Research, Zagreb \\ UDK: $373.211 .24: 159.942$ \\ 373.211.24:159.923.2 \\ Izvorni znanstveni članak / Original scientific paper
}

Primljeno / Received: 12. XII. 2014.

\begin{abstract}
Cilj istraživanja bio je pronaći povezanost između sagorijevanja u radu, emocionalne kompetencije i dvije karakteristike posla: socijalne podrške na poslu te mogućnosti kontrole na poslu. Ispitali smo uzorak od 112 odgajateljica četiri zagrebačka dječja vrtića. Nastojali smo utvrditi povezanost između: doživljaja sagorijevanja u radu i emocionalne kompetencije; emocionalne kompetencije i dvije karakteristike posla (socijalne podrške na poslu te mogućnosti kontrole na poslu); doživljaja sagorijevanja u radu i navedene dvije karakteristike posla. Koristili smo instrumentarij: Upitnik za ispitivanje percepcije i doživljaja posla te Upitnik emocionalne kompetencije UEK-45. Rezultati su pokazali da nema statistički značajne povezanosti između emocionalne kompetencije i doživljaja sagorijevanja u radu, kao ni između emocionalne kompetencije i nekih karakteristika posla (percipirane socijalne podrške i mogućnosti kontrole na poslu). Pronašli smo statistički značajnu pozitivnu povezanost između doživljaja sagorijevanja u radu i navedenih karakteristika posla. Međutim, ključno je napomenuti da su sve pronađene statistički značajne povezanosti zapravo vrlo niske.
\end{abstract}

KLJUČNE RIJEČI: mogućnost kontrole na poslu, odgajateljice, povezanost, socijalna podrška

\section{UvOD}

Doživljaj sagorijevanja u radu uvjetovan je karakteristikama posla odgajateljica predškolske djece, ali i njihovim karakteristikama ličnosti te stručnim i emocionalnim kompetencijama. Stoga nam uvid u odnos doživljaja sagorijevanja u radu, emocionalne kompetencije i obilježja posla može pružiti važne informacije za prevenciju doživljaja sagorijevanja na poslu putem edukacije o emocionalnim vještinama ili, jednostavno, promjene radnog ustroja u dječjem vrtiću.

Budući da su specifičnosti odgajateljskog posla svakodnevna izloženost višestrukim interakcijama i odnosima, i to s djecom različite razvojne razine te odraslima (roditelji, 
kolege, nadređeni), odgajatelj mora posjedovati određene kompetencije u ophođenju s ljudima, ali i znati upravljati svojim emocijama. Sve navedene aspekte pokriva koncept emocionalne kompetencije. Nadalje, odgajatelji koji doživljavaju posao kao prijeteći, prenaporan i stresan imaju više zdravstvenih problema, češće izostaju s posla, manje su zadovoljni poslom te su općenito manje posvećeni radu, a sve navedeno odražava se i na samu djecu. Stoga je, s ciljem poduzimanja odgovarajućih intervencija u radu s odgajateljima, nužno razumjeti izvor stresa i opterećenosti poslom.

\section{I.I. DOŽIVLJAJ SAGORIJEVANJA U RADU}

Stanje stresa na radnom mjestu može se opisati kao niz za pojedinca štetnih fizioloških, psiholoških i bihevioralnih reakcija na situacije u kojima zahtjevi posla nisu u skladu s njegovim sposobnostima, mogućnostima i potrebama (Sauter i sur., 1997). Izvori profesionalnog stresa mogu biti unutrašnji i vanjski (Ajduković, 1996). Unutrašnji izvori stresa prvenstveno ovise o pojedincu, a očituju se kao nerealna očekivanja od posla i od sebe, potreba za stalnom i potpunom kontrolom situacije, pretjerana vezanost za posao i osjećaj pojedinca da snosi svu odgovornost, ne delegiranje poslova drugima te pretjerana upornost i rigidnost u postizanju cilja po bilo koju cijenu. Vanjski izvori profesionalnog stresa povezani su s radnim uvjetima, organizacijom rada i odnosima s drugim ljudima (Škrinjar, 1994).

Fenomen stresa i ispitivanje stresnosti posla prosvjetnih radnika sve se češće izučavaju upravo s ciljem osiguravanja intervencije putem razumijevanja fenomena stresa $u$ odgojno-obrazovnim pozivima. Tako u modelu nastavničkog stresa (Kyriacou, 1981) razlikuju dominantno fizičke stresore (npr. prevelik broj djece) od psiholoških (npr. loši odnosi s kolegama). Nadalje, kao glavne izvore stresa u nastavnika ili odgajatelja navode se rad s nemotiviranom djecom, održavanje discipline, vremenski pritisak i zatrpanost administrativnim poslom, suočavanje s promjenama, izloženost stalnoj procjeni od strane drugih osoba, odnosi s kolegama, samopoštovanje i status, administracija i upravljanje, konflikt uloga te slabi radni uvjeti (Kyriacou, 1981). Slično prepoznaju i Boyle i sur. (1995), koji ističu teškoće u provođenju discipline s djecom, probleme u organizaciji vremena, prepoznavanje profesionalnih potreba i slabe odnose s kolegama. U pregledu istraživanja o stresu odgajatelja i nastavnika, Friedman (2000) pak ističe konflikt uloga, vremenske zahtjeve, velike odjele, problematičnu djecu, loše odnose među kolegama i neodgovarajuće radne uvjete. Ipak, bitno je napomenuti da razina stresa koju doživljava pojedini odgajatelj ovisi o njegovim osobinama ličnosti, vrijednostima, vještinama i okolnostima. Hoće li nešto biti izvor stresa nastavniku ili odgajatelju ovisi o njegovoj procjeni rizika te o procjeni osobnih resursa u suočavanju sa stresom.

Jedna od najnepovoljnijih posljedica dugotrajne izloženosti profesionalnom stresu (Ajduković, 1996), koja nastaje kao reakcija na kronične izvore stresa u radu, upravo je sagorijevanje na poslu. Njegovi najčešći znaci su: osjećaj tjelesne i emocionalne iscrpljenosti, gubitak osjećaja osobne vrijednosti, negativizam, gubitak zanimanja za suradnike, cinizam i neosjetljivost, osjećaj bespomoćnosti, razdražljivost i niska tolerancija na frustraciju, srdžba, neprijateljstvo, sumnjičavost, rigidnost i neprilagodljivost, povlačenje u društvenim odnosima, učestaliji sukobi i agresivni ispadi, povećana upotreba alkohola, duhana, stimulirajućih sredstava i lijekova, izostajanje s posla, osjećaj opće slabosti, učestalo 
pobolijevanje, preosjetljivost na podražaje, komunikacijske poteškoće, gubitak seksualnog interesa i nastanak seksualnih problema te tjelesni simptomi (glavobolje, bolovi u leđima, poteškoće disanja, spavanja i prehrane, gastrointestinalni poremećaji).

Bitno je znati da se sagorijevanje na poslu odvija postupno. Prvo se javljaju prevelika očekivanja i idealizacija posla, a manifestiraju kao entuzijazam i potpuna posvećenost poslu, visok stupanj energije, pozitivni i konstruktivni stavovi te dobro postignuće. Zatim se javlja početno nezadovoljstvo poslom i prvi znakovi sagorijevanja: tjelesni i mentalni umor, frustriranost i gubitak nekih ideala te smanjenje radnog morala. Povećavaju se dosada i teškoće u komunikaciji s kolegama, dolazi do povlačenja i izolacije te intenzivnijih znakova stresa: izbjegavanje kontakta sa suradnicima, veće komunikacijske poteškoće, srdžba i neprijateljstvo spram okoline, negativizam, depresija i druge emocionalne poteškoće, nesposobnost da se misli i koncentrira, tjelesna i mentalna iscrpljenost te veći broj psihosomatskih teškoća. U konačnici može doći do apatije i gubitka interesa uz ozbiljno produbljivanje znakova stresa: niskog osobnog i profesionalnog samopoštovanja, kroničnog izostajanja s posla, stalnih negativnih osjećaja vezanih uz posao, potpuni cinizam, nesposobnost komuniciranja s drugim osobama, depresija i tjeskobnost te, na kraju, napuštanje posla (Ajduković, 1996).

Jedna od najpoznatijih istraživačica fenomena sagorijevanja u SAD-u, Christina Maslach, navodi tri osnovne dimenzije ili faze sagorijevanja: emocionalnu iscrpljenost, depersonalizaciju i smanjeno osobno postignuće, koji se pojavljuju kod pojedinaca koji rade s ljudima (Auerbach i Gramling, 1998). Emocionalna iscrpljenost odnosi se na osjećaj nemogućnosti davanja drugima - emocionalno iscrpljena osoba ima osjećaj da su njeni emocionalni resursi osiromašeni ili oslabljeni, što rezultira gubitkom energije i slabošću. Depersonalizacija znači ravnodušan i bezosjećajan odnos prema osobama koje primaju pomoć, tj. mentalno distanciranje, što može prerasti i u neosjetljivo ili neprilagođeno ponašanje prema klijentima i povlačenje od njih. Smanjeno osobno postignuće odnosi se na opadanje osjećaja kompetencije i uspješnog postignuća u radu s ljudima, što vodi gubitku samopoštovanja i depresiji (Auerbach i Gramling, 1998).

Nadalje, Kaliath i Beck (2001) navode da je emocionalna iscrpljenost srž doživljavanja sagorijevanja u radu, te je snažno povezana s ostalim komponentama sagorijevanja. Maslach i Jackson (1981) smatraju da je depersonalizacija obrambeni odgovor, odnosno način na koji se pojedinac snosi s emocionalnom iscrpljenošću kada ostali načini suočavanja nisu dostupni. Uz to, nezadovoljstvo osobnim postignućem proizlazi dijelom iz depersonalizacije tako da osobe doživljavaju negativne osjećaje prema sebi, osjećaju da su pod stresom, kao što osjećaju i krivnju za način na koji su mislili ili se ponašali prema drugima, što dovodi do osjećaja smanjenog osobnog postignuća. Takvi pojedinci osjećaju da njihov trud ne dovodi do rezultata te se prestaju truditi.

Primjenom metode dnevnika i analize sadržaja na temelju iskaza nekoliko odgajatelja, Kelly i Berthelsen (1997) zaključuju kako su vremenski pritisak, zadovoljenje potreba djece, suočavanje s poslovima izvan svoje profesionalne domene, zadovoljenje osobnih potreba, interakcija s roditeljima djece u vrtiću, interpersonalni odnosi te stalne prilagodbe promjenama predškolskog kurikuluma dominantna područja koje odgajatelji smatraju stresnima. 
U odnosu na navedeno te kako bi se prevenirao doživljaj sagorijevanja u radu, potrebno je poboljšati sposobnosti odgajatelja da se suočavaju sa stresnim situacijama putem interaktivnih edukacija o prirodi stresa, kao i učenjem vještina čija bi primjena trebala reducirati stres i pospješiti suočavanje sa stresom. Na taj se način može djelovati na poboljšanje zadovoljstva poslom te na kvalitetu izvođenja odgojno-obrazovnog procesa.

\section{I.2. EMOCIONALNA KOMPETENCIJA}

Kao konstrukt, emocionalna je inteligencija prvi put operacionalizirana od strane Saloveya i Mayera (1990), a definirali su je kao sposobnost opažanja, asimilacije, razumijevanja i upravljanja emocijama (Mayer i Salovey, 1990), tj. sposobnost brzog zapažanja procjene i izražavanja emocija; sposobnost uviđanja i generiranja osjećanja koja olakšavaju mišljenje; sposobnost razumijevanja emocija i znanje o emocijama; te sposobnost reguliranja emocija u svrhu promocije emocionalnog i intelektualnog razvoja (Takšić i sur., 2006). Također razlikuju četiri strukturalne razine, tj. grane sposobnosti u konstruktu emocionalne inteligencije:

1) refleksivna regulacija emocija u promociji emocionalnog i intelektualnog razvoja (D razina)

2) razumijevanje i analiza emocija: upotreba emocionalnih znanja ( $\mathrm{C}$ razina)

3) emocionalna facilitacija mišljenja ili misaona asimilacija emocija (B razina)

4) percepcija, procjena i izražavanje emocija (A razina).

Razina A je na najmanjoj razini složenosti psiholoških procesa, a razina D na najsloženijoj. Svaka od njih definirana je s još četiri sposobnosti nižeg hijerarhijskog reda. Emocionalno inteligentnije osobe trebale bi brže i u većem broju i mjeri svladati navedene razine sposobnosti (Mayer i Salovey, 1990).

Razina A (percepcija, procjena i izražavanje emocija) predstavlja najjednostavniju emocionalnu sposobnost pomoću koje pojedinac zapaža koje se emocije kriju iza nečijeg fizičkog stanja, te vlastitog i tuđeg osjećaja i razmišljanja (A1). Također, pojedinac je u određenoj mjeri sposoban prepoznati emocije u umjetničkim djelima (A2) te u drugim živim i neživim objektima. Uz sposobnost da manje ili više precizno izrazi svoje emocije, pojedinac putem njih izražava i potrebe vezane uz te osjećaje (A3). Sposobnost razlikovanja iskrenih od lažno izraženih emocija omogućava pojedincu da spriječi manipulaciju od strane drugih osoba lažnim izražavanjem emocija (A4) (Mayer i Salovey, 1990).

Razina B (emocionalna facilitacija mišljenja) odnosi se na načine na koji emocije mogu pospješiti intelektualno funkcioniranje. Naime, fokusiranjem pažnje na određeni događaj (B1) emocije pomažu boljem pamćenju tog događaja i time efikasnijoj procjeni slične situacije koja se u životu može ponoviti. Salovey i Mayer (1990) navode kako emocionalno inteligentna osoba pri planiranju svog djelovanja stvara u glavi „zamišljeno emocionalno kazalište" u kojem generira, manipulira i provjerava moguće ishode svojih odluka. Što ovaj sustav bolje funkcionira, to će osoba biti u stanju pronaći one strategije djelovanja koje će biti najbolje za ostvarenje njenih ciljeva (B2). Sposobnost pojedinca da mijenja svoja emocionalna raspoloženja pomaže mu da neki problem sagleda iz različitih perspektiva, što povećava vjerojatnost nalaženja rješenja (B3). Istraživanja su 
pokazala da emocije direktno utječu na kvalitetu misaonih procesa. Primjerice, sreća poboljšava efikasnost induktivnog rezoniranja i kreativnog djelovanja, za razliku od tužnih raspoloženja koja su pogodnija za rješavanje zadataka koji zahtijevaju analitičko mišljenje (B4) (Mayer i Salovey, 1990).

Razina C odnosi se na sposobnost razumijevanja emocija i primjenjivanja emocionalnog znanja. Pojedinac treba biti u stanju razlikovati emocije: imenovati potpuno različite emocije ili razlikovati istu emociju prema njezinom intenzitetu (npr. razlika između sviđati se i voljeti, ljutnje i bijesa i sl.). Emocionalno inteligentnije osobe imaju istančaniji osjećaj za ovakvu vrstu osjetljivosti (C1). Sposobnost da se pronikne u uzrok nastanka neke emocije (C2) preduvjet je za razumijevanje mnogostrukih osjećaja (C3). Sposobnost pojedinca da prepozna tijek razvoja neke emocije i prijelaza iz emocije u emociju (C4) preduvjet je mogućnosti da se efikasno upravlja takvim emocijama (Mayer i Salovey, 1990).

Razina D (refleksivna regulacija emocija u promociji emocionalnog i intelektualnog razvoja) predstavlja najsloženiju razinu emocionalne inteligencije i omogućava pojedincu da svjesno upravlja vlastitim emocijama te tako doprinese vlastitom emocionalnom i intelektualnom napretku. Preduvjet efikasnog upravljanja vlastitim emocijama je spremnost na otvorenost prema emocijama, ugodnim ili neugodnim (D1). A ako se neka emocija procijeni nekorisnom, također je potrebno imati sposobnost odvajanja od iste (D2). Stoga emocionalna sposobnost navedena u okviru odjeljka D2 zahtijeva ispravnu procjenu korisnosti, a potom na osnovi tih informacija i sposobnost odvajanja ili uživljavanja u neko emotivno stanje. S rastom i razvojem pojedinca poboljšava se i njegova sposobnost refleksivnog praćenja emocija (Mayer i Salovey, 1990).

Za razliku od tradicionalnog shvaćanja - u kojemu emocije dezorganiziraju i ometaju uspješnu i racionalnu mentalnu aktivnost - u suvremenom emocije mogu, ako se njima ispravno upravlja, pokrenuti i poboljšati racionalno gledanje pojedinca, što djeluje na povećanje motivacije za rješavanje problema za koji je neophodno racionalno rezoniranje (Mayer i Salovey, 1990). Nadalje, refleksivna regulacija emocija će poboljšati socijalnu adaptaciju, omogućiti smirivanje nakon stresnih emocija i ublažavanje stresnih emocija kod drugih ljudi (Roberts i sur., 2003).

U svezi s navedenim je i emocionalna kompetencija, koju Goleman (1998) definira kao naučenu sposobnost baziranu na emocionalnoj inteligenciji koja rezultira izvrsnom izvedbom na poslu. Emocionalna inteligencija se promatra kad osoba pokazuje kompetencije koje sadrže samosvijest, samoupravljanje, socijalnu svijest i socijalne vještine u pravo vrijeme i na pravom mjestu u dovoljnoj mjeri da bi bile učinkovite u danoj situaciji (Jayan, 2006), pa stoga koncept emocionalne kompetencije pokazuje koliko je od tog potencijala preneseno u poslovne sposobnosti, iako emocionalna kompetentnost osobe ne mora uvijek točno preslikavati razinu njezine emocionalne inteligencije (Takšić i sur., 2006).

Istraživanja pokazuju da se emocionalna kompetencija razvija u funkciji dobi i iskustva (Takšić i sur., 2006). Naprimjer, ispitujući relaciju između godina iskustva u zdravstvenom radu i emocionalne kompetencije na australskom uzorku medicinskih sestara, Humpel i sur. (2001) dobili su značajnu povezanost između emocionalne kompetencije i godina iskustva. Sestre sa šest i više godina iskustva pokazivale su više razine emocionalne kompetencije. Nadalje, ova je tendencija bila naglašenija za ženske ispitanike nego za muške. Također, u istraživanju koje se bavilo odnosom emocionalne kompetencije i 
mentalnog zdravlja (mjerenog s tri varijable: depresija, beznađe i suicidalne ideacije), emocionalna je kompetencija bila važan moderator između stresa i mentalnog zdravlja (Ciarrochi i sur., 2000). Dosljedni su rezultati i u pogledu smjera povezanosti i zadovoljstva međuljudskim odnosima: osobe s većim rezultatima na skali emocionalne kompetencije bile su zadovoljnije međuljudskim odnosima, a ova povezanost ostala je značajna i nakon parcijalizacije efekata osobina ličnosti i verbalne inteligencije (Lopez i sur,. 2003).

Tijekom zadnjih desetljeća vidljivo se povećava interes za programima koji se bave razvijanjem emocionalnih i socijalnih vještina, poput donošenja odluka, komunikacijskih vještina, prepoznavanja vlastitih i tuđih emocija, nošenja s emocijama na primjeren način, upravljanje vlastitim ponašanjem i sl. Takav interes proizlazi iz potrebe za unapređenjem različitih aspekata socijalnog (veća socijalna podrška i sl.) i mentalnog zdravlja (veće zadovoljstvo životom, manja depresivnost i sl.). Istraživanja pokazuju da se trening razvoja emocionalne kompetencije pokazuje korisnim u smanjenju stresa te unapređenju menadžerskih sposobnosti (Takšić i sur., 2006) te su dobivene pozitivne povezanosti emocionalne inteligencije s konstruktima poput sreće, samopoštovanja, samoefikasnosti, optimizma, nade, zadovoljstva životom, lokusa kontrole i dr. (Furr, 2005).

\section{I.3. DoŽivljaj SAgorijeVAnja U RADU I EMOCIONALNA KOMPETENCIJA}

Budući da se danas uvode mnoge promjene u odgojnoobrazovnom procesu, a za mnoge zaposlenike posao postaje zahtjevniji i kompleksniji, veća je i vjerojatnost pojave doživljaja stresa. Općenito, s povećanom razinom poslovnih zahtjeva, povećava se i doživljaj stresa te posljedično i vjerojatnost doživljaja sagorijevanja.

Budući da se neki od faktora koji izazivaju stres u odgajateljskom poslu ne mogu otkloniti i kako bismo negativni utjecaj opisanih faktora izbjegli (ili barem ublažili), nužno je utjecati na promjenu percepcije stresnih situacija kod odgajatelja razvijanjem određenih vještina koje će služiti kao moderatori između stresne situacije i percipiranog stresa te utvrditi koje vještine mogu poslužiti kao ublaživači stresa.

Mnoga istraživanja pokazuju da je upravo emocionalna kompetencija jedan od tih faktora između stresne situacije i percepcije stresa, koji potencijalno djeluje u poželjnom smjeru, dakle, reduciraju doživljeni stres (Jordan i sur., 2002; Abraham, 2000; Slaski i Cartwright, 2003). Naime, niska razina emocionalne kompetencije povezana je s naglašenijim doživljajem negativnih emocionalnih reakcija na nesigurnost posla i s usvajanjem negativnih strategija suočavanja sa stresom, a pojedinci s većom emocionalnom kompetencijom uspješnije će se nositi sa stresom, odnosno opterećenošću poslom (Schutte i sur., 1998). Emocionalna kompetencija određuje i kvalitetu komunikacije, kao i kvalitetu odnosa sa djecom, kolegama te nadređenima. Takve su osobe otvorenije za vlastite emocije i emocije drugih te sposobne pojačavati pozitivne emocije i umanjivati negativne bez umanjivanja ili prenaglašavanja informacija koje prenose emocije. Također ostavljaju dojam stabilne i sposobne osobe, što, prema našim očekivanjima, može imati pozitivan efekt na međuljudske odnose, uključujući i razinu primanja podrške od strane kolega i nadređenih. 
Nadalje, emocionalno kompetentni pojedinci u manjoj su mjeri fiksirani na ograničenja, a u većoj nalaze prilike za djelovanje, što im daje percepciju veće mogućnosti kontrole na poslu. Manja mogućnost kontrole na poslu vodi do veće vjerojatnosti doživljaja stresa, a na duže staze i sagorijevanja u radu (Demerouti i sur., 2001). Istraživanja također pokazuju da je izostanak socijalne podrške na poslu povezan s doživljajem sagorijevanja u radu (Živčić Bećirević i Smojver-Ažić, 2005). Budući da su pojedinci koji imaju visok doživljaj sagorijevanja u radu često neprijateljski nastrojeni prema drugima, imaju ispade agresije i sl., očekujemo da će i u ovom istraživanju doživljaj sagorijevanja i percipirana socijalna podrška biti povezani u negativnom smjeru (veća socijalna podrška - manji doživljaj sagorijevanja). Sukladno navedenom, pretpostavljamo značajnu povezanost emocionalne kompetencije, doživljaja sagorijevanja u radu, percipirane socijalne podrške i mogućnosti kontrole na poslu.

Glavni cilj ovoga rada odnosi se na ispitivanje povezanosti između emocionalne kompetencije te obilježja vezanih uz posao: doživljaja sagorijevanja u radu te nekih karakteristika posla (percipirane socijalne podrške i mogućnosti kontrole na poslu).

U skladu s ciljem istraživanja formulirani su sljedeći podciljevi:

1) Ispitati povezanost emocionalne kompetencije i doživljaja sagorijevanja u radu. (Pretpostavili smo da je veći stupanj emocionalne kompetencije povezan s manjim doživljajem sagorijevanja u radu.)

2) Ispitati povezanost emocionalne kompetencije i dvije karakteristike posla, socijalne podrške na poslu te mogućnosti kontrole na poslu. (Pretpostavili smo da je veći stupanj emocionalne kompetencije povezan s većom percipiranom socijalnom podrškom na poslu te doživljenom mogućnosti kontrole na poslu.

3) Ispitati povezanost doživljaja sagorijevanja u radu i dvije karakteristike posla, socijalne podrške na poslu te mogućnosti kontrole na poslu. (Pretpostavili smo da je veći doživljaj sagorijevanja u radu, povezan s manjom percipiranom socijalnom podrškom na poslu te doživljenom mogućnosti kontrole na poslu).

\section{Metoda}

\section{I. Sudionice}

U istraživanju je sudjelovalo 112 odgajateljica, zaposlenica četiri dječja vrtića u gradu Zagrebu (DV Kustošija, DV Jarun, DV Siget i DV Botinec). Zbog nepotpuno ili nepravilno ispunjenih upitnika, u konačnu obradu rezultata uvršteni su rezultati 101 sudionice (sve su ženskog spola), dobi u rasponu između 22-60 godina. Uzorak ispitanika je odabran je na način da je svim odgajateljicama u navedenim vrtićima ponuđena mogućnost sudjelovanja $\mathrm{u}$ istraživanju, a u finalni uzorak ušle su one koje su dobrovoljno pristale na popunjavanje upitnika. 


\subsection{VARIJABLE I INSTRUMENTI}

U Tablici 1. dan je pregled svih varijabli u istraživanju.

Tablica 1. Varijable u istraživanju

\begin{tabular}{|c|c|c|c|c|}
\hline Konstrukt & Simbol & Varijable & Mjerni instrument & Broj čestica \\
\hline \multirow{3}{*}{$\begin{array}{l}\text { Emocionalna } \\
\text { kompetencija }\end{array}$} & SURE & $\begin{array}{l}\text { Sposobnost uočavanja i } \\
\text { razumijevanja emocija }\end{array}$ & UEK-45 & 15 \\
\hline & SIIE & $\begin{array}{c}\text { Sposobnost izražavanja i } \\
\text { imenovanja emocija }\end{array}$ & UEK-45 & 14 \\
\hline & SUE & $\begin{array}{c}\text { Sposobnost upravljanja } \\
\text { emocijama }\end{array}$ & UEK-45 & 16 \\
\hline $\begin{array}{c}\text { Socijalna podrška } \\
\text { na poslu }\end{array}$ & SP & Socijalna podrška na poslu & \multirow{2}{*}{$\begin{array}{l}\text { Upitnik za ispitivanje } \\
\text { percepcije i doživljaja } \\
\text { posla-Osobine posla }\end{array}$} & 6 \\
\hline $\begin{array}{c}\text { Mogućnost } \\
\text { kontrole na poslu }\end{array}$ & KP & $\begin{array}{l}\text { Mogućnost kontrole na } \\
\text { poslu }\end{array}$ & & 3 \\
\hline \multirow{3}{*}{$\begin{array}{l}\text { Doživljaj } \\
\text { sagorijevanja u } \\
\text { radu }\end{array}$} & EI & Emocionalna iscrpljenost & \multirow{3}{*}{$\begin{array}{c}\text { Upitnik za ispitivanje } \\
\text { percepcije i doživljaja } \\
\text { posla- Opterećenost } \\
\text { poslom }\end{array}$} & 9 \\
\hline & NOP & $\begin{array}{c}\text { Nezadovoljstvo osobnim } \\
\text { postignućem }\end{array}$ & & 6 \\
\hline & $\mathrm{D}$ & Depersonalizacija & & 8 \\
\hline
\end{tabular}

\subsection{TEST EMOCIONALNE KOMPETENTNOSTI (UEK-45)}

UEK-45 je skraćena verzija Upitnika emocionalne inteligencije UEK-136 (Takšić, 1998), konstruiranog po modelu Mayera i Saloveya (1990). Skala upitnika emocionalne kompetentnosti procjenjuju ono što se u literaturi često naziva emocionalna inteligencija kao osobina ličnosti. Ipak, zbog čestih prigovora da se inteligencija može mjeriti jedino testovima sposobnosti, Takšić se odlučio za sintagmu „emocionalna kompetentnost“ (Takšić i sur., 2006). Upitnik sadrži 45 čestica, podijeljenih u tri supskale koje procjenjuju: sposobnost uočavanja i razumijevanja emocija (15 čestica), sposobnost izražavanja i imenovanja emocija (14 čestica) te sposobnost upravljanja emocijama (16 čestica). Svaka supskala sadrži tvrdnje za koje ispitanik procjenjuje na skali Likertova tipa od 1 do $5 \mathrm{u}$ kojoj se mjeri odnose na njega osobno, pri čemu 1 znači da se navedena tvrdnja uopće ne odnosi na njega, a 5 da se tvrdnja u potpunosti odnosi na njega. Veći rezultat ukazuje na veću razinu emocionalne kompetencije, odnosno (na pojedinim supskalama) na veću sposobnost uočavanja i razumijevanja emocija, veću sposobnost izražavanja i imenovanja emocija te veću sposobnost upravljanja emocijama. Ukupan rezultat svakog ispitanika za pojedinu supskalu Skale emocionalne kompetencije dobiven je dijeljenjem sume rezultata čestica pojedine supskale s brojem čestica koje čine pojedinu supskalu.

Do sada je skalom ispitano više od 7000 ispitanika različite dobi i spola te je prevedena na engleski, švedski, finski, portugalski, španjolski, japanski, slovenski i talijanski jezik. Psihometrijske karakteristike UEK-45 uglavnom su dobre, pa je tako pouzdanost cijelog upitnika u različitim uzorcima od 0,88 do 0,92 . Pouzdanosti pojedinačnih skala također su prihvatljive. Tako je ona za Skalu sposobnosti uočavanja i razumijevanja emocija najveća i iznosi od 0,82 do 0,88. Za Skalu sposobnosti izražavanja i imenovanja emocija iznosi 
između 0,78 i 0,81 , dok je nešto niža za Skalu sposobnosti upravljanja emocijama, gdje su dobivene vrijednosti od 0,68 do 0,72 (Takšić i sur, 2002). Korelacija između pojedinih supskala kreće se od 0,35 do 0,51, pa se ukupan rezultat može formirati kao mjera opće emocionalne kompetentnosti s pouzdanošću između 0,87 i 0,92.

U ovom istraživanju, za cijeli upitnik Cronbachov alpha iznosi 0,90. Za skalu sposobnosti uočavanja i razumijevanja emocija alpha iznosi 0,87 , za skalu sposobnosti izražavanja i imenovanja emocija alpha iznosi 0,84 , za skalu sposobnosti upravljanja emocijama alpha iznosi 0,72 .

\subsubsection{UPITNIK ZA ISPITIVANJE PERCEPCIJE I DOŽIVLJAJA POSLA}

Upitnik za ispitivanje percepcije i doživljaja posla se sastoji od četiri dijela (VizekVidović, Arambašić i Vlahović-Štetić, 1997, prema Bašić, 1999). Prvi je dio vezan uz opće podatke o ispitaniku (8 čestica). Drugi se dio odnosi na osobine posla, a sastoji se od skale za ispitivanje osobina posla Likertova tipa (od 1 - uopće nije točno do 4 - potpuno točno, odnosno od 1 - vrlo malo do 4 - jako puno, ovisno o sadržaju čestice) te jednog pitanja u kojem je potrebno rangirati tri glavna izvora nezadovoljstva i frustracije na poslu. Skala za ispitivanje posla (Vizek-Vidović, Arambašić i Vlahović-Štetić, 1997, prema Bašić, 1999) sadrži tri supskale, budući da je konstruirana u skladu s Karasekovim modelom zahtjevnosti/kontrolabilnosti posla za predviđanje doživljaja sagorijevanja u radu, a to su:

a. supskala za ispitivanje psiholoških zahtjeva posla - tri čestice tipa „Moj posao...“ i šest čestica obilježja posla;

b. supskala za ispitivanje mogućnosti kontrole u radu - tri čestice tipa „Na svom poslu mogu...";

c. supskala za ispitivanje socijalne podrške u radu - tri čestice vezane uz nadređenog i tri vezane uz kolege na poslu kao izvore socijalne podrške.

Treći se dio odnosi na Opterećenost poslom i sastoji od kategorizacije prethodno navedenih znakova stresa na emocionalne, kognitivne, tjelesne i ponašajne znakove, zatim jednog pitanja o psihosomatskim smetnjama i oboljenjima te skale za ispitivanje doživljaja sagorijevanju radu (Maslach Burnout Inventory, Maslach i Jackson, 1986, prema ŽivčićBećirević i sur., 2005) adaptirane za našu populaciju. Skala je Likertova tipa i sadrži 23 čestice, a treba procijeniti njihovu istinitost (1 - nimalo istinita, 2 - pomalo istinita, 3 prilično istinita, 4 - potpuno istinita). Skala za ispitivanje doživljaja sagorijevanja u radu sastoji se od tri supskale koje treba razmatrati zasebno (Živčić-Bećirević i sur., 2005), a to su emocionalna iscrpljenost, depersonalizacija i nezadovoljstvo osobnim postignućem.

Četvrti dio odnosi se na Očekivanja od posla i sastoji od Skale za ispitivanje mogućnosti zadovoljenja očekivanja od posla te jednog pitanja o izvorima zadovoljstva na poslu. Skala je Likertova tipa i sadrži 20 čestica tipa: „U kojoj mjeri na svom poslu možete...“, u rasponu od 0 - nije mi važno do 4 - važno mi je i potpuno mogu ostvariti.

Za potrebe ovog rada korišteni su podatci dobiveni na supskalama za ispitivanje mogućnosti kontrole i percipirane socijalne podrške u radu, kao i skali za ispitivanje doživljaja sagorijevanja u radu te njenim supskalama. Ukupan rezultat svakog ispitanika za pojedinu supskalu Skale za ispitivanje doživljaja sagorijevanja u radu dobiven je, kao i u slučaju supskala emocionalne kompetencije, dijeljenjem sume rezultata čestica pojedine supskale s brojem čestica koje čine pojedinu supskalu. 
Pouzdanost je provjerena Cronbach alpha koeficijentom unutarnje konzistencije. Dobiveni koeficijenti pouzdanosti su zadovoljavajući za skalu doživljaja sagorijevanja $\mathrm{u}$ radu (GOS $-\alpha=0.88$ ) te njene supskale: emocionalna iscrpljenost (EI $-\alpha=0.85$ ), depersonalizacija $(\mathrm{D}-\alpha=0.59)$ i nezadovoljstvo osobnim postignućem (NOP $-\alpha=0.70)$. Pouzdanost je vrlo visoka jedino za skalu za ispitivanje doživljaja sagorijevanja u radu te za supskalu emocionalne iscrpljenosti. Za neke karakteristike posla, nezadovoljstva osobnim postignućem $(\alpha=0.70)$ i mogućnost kontrole na poslu $(\alpha=0.62)$ dobiveni koeficijenti pouzdanosti su relativno niski, dok je kod skale percipirane socijalne podrške $(\alpha=0.49$ ) pouzdanost ispod zadovoljavajuće razine pouzdanosti.

\subsection{Postupak}

Primjene upitnika su provedene na stručnim aktivima vrtića (u svakom vrtiću u dva navrata), pri čemu je rezultate prikupljao isti ispitivač. Primijenjena su 2 upitnika - Upitnik emocionalne kompetencije (UEK-45) (Takšić, 2002) i Upitnik za ispitivanje percepcije i doživljaja posla (Vizek-Vidović, Arambašić i Vlahović-Štetić, 1997, prema Bašić, 1999). Redoslijed ispunjavanja upitnika je variran kako bi se izbjegao učinak redoslijeda.

Sudionicama je priopćeno da će sudjelovati u istraživanju te da se žele ispitati neka njihova mišljenja i osjećanja. Također im je rečeno da će ispunjavati dva upitnika, da za vrijeme ispitivanja budu usmjerene na rješavanje upitnika, da je ispitivanje anonimno te da stoga uistinu mogu napisati ono što misle ili osjećaju, bez straha da će netko imati uvid u njihove odgovore. Sugerirano im je da umjesto imena i prezimena na oba upitnika napišu istovjetnu šifru. Uz svaki upitnik bila je pročitana odgovarajuća uputa i naglašeno da slobodno postave pitanja u slučaju nejasnoća.

\subsection{Metode statističKe analize}

Obrada rezultata provedena je primjenom statističkog programa Statistical Program for Social Scientists 11 (SPSS 11). Za potrebe opće deskripcije rezultata izračunate su aritmetičke sredine i standardne devijacije rezultata, a za testiranje normaliteta distribucije korišten je Kolmogorov-Smirnovljev test (K-S). Premda je u analizi testiranje normaliteta distribucije utvrđeno da varijable sagorijevanja na poslu statistički značajno odstupaju od Gaussove krivulje (Tablica 2.), svejedno smo u daljnjim analizama koristili parametrijske metode analize podataka, budući da je ispitani uzorak ispitanika dovoljno velik, a distribucije nisu bimodalne, odnosno približno su simetrične (Petz, 2002). Korelacija između varijabli unutar istih skupova (interkorelacije unutar skupova dimenzija emocionalne kompetencije, doživljaja sagorijevanja na poslu, te dvije karakteristike posla) izračunata je primjenom Pearsonova koeficijenta korelacije.

Pouzdanost Upitnika emocionalne kompetencije (UEK-45) i Upitnika za ispitivanje percepcije i doživljaja posla odredit će se na temelju koeficijenta Cronbach alpha. Kao osnovu za tumačenje dobivenih koeficijenata pouzdanosti, korišten je kriterij koji je predložio Nunnally (1978), koji sugerira da je dovoljan stupanj pouzdanosti potreban da bi se neki mjerni instrument koristio u istraživanjima ličnosti onaj koji varira u rasponu od 0,50 do 0,80 . S druge strane, za primjenu u praksi nužna je puno viša razina pouzdanosti, 
od 0,90 na više, npr. u psihodijagnostičke svrhe (Nunnally, 1978). Dakle, za sve supskale, kao i za cijeli upitnik, koeficijent pouzdanosti razine koja se smatra zadovoljavajućom za upitnike ličnosti (Nunnally, 1978).

Kanoničkom korelacijskom analizom utvrdit će se povezanosti između skupa dimenzija emocionalne kompetencije, doživljaja sagorijevanja na poslu te dvije karakteristike posla (mogućnosti kontrole na poslu i percipirane socijalne podrške). Zbog dobivanja detaljnijeg uvida u povezanost pojedinih dimenzija skupova varijabli izračunate su kroskorelacije (Pearsonovi koeficijenti korelacije).

\section{ReZultati}

Izračunati su osnovni deskriptivni pokazatelji za skale emocionalne kompetencije, skale za ispitivanje doživljaja sagorijevanja u radu, skale percipirane socijalne podrške i skale mogućnosti kontrole na poslu (Tablica 2.).

Tablica 2. Deskriptivni pokazatelji (emocionalna kompetencija, doživljaj sagorijevanja u radu, osjećaj kontrole na poslu i percipirane socijalne podrške)

\begin{tabular}{|l|c|c|c|c|c|}
\hline \multicolumn{1}{|c|}{ Skale } & $\operatorname{min.}$ & $\operatorname{max.}$ & $\mathbf{M}$ & s.d. & $\begin{array}{c}\text { Kolmogorov- } \\
\text { Smirnov Test }\end{array}$ \\
\hline Generalna emocionalna kompetencija & 3 & 4,78 & 3,76 & 0,33 & 0,84 \\
\hline $\begin{array}{l}\text { Skala sposobnosti uočavanja i razumijevanja } \\
\text { emocija }\end{array}$ & 2,8 & 4,93 & 3,65 & 0,40 & 0,68 \\
\hline $\begin{array}{l}\text { Skala sposobnosti izražavanja i imenovanja } \\
\text { emocija }\end{array}$ & 3 & 4,79 & 3,84 & 0,42 & 0,79 \\
\hline Skala sposobnosti upravljanja emocijama & 3 & 4,69 & 3,81 & 0,35 & 1,15 \\
\hline Generalni doživljaj sagorijevanja & 1 & 2,61 & 1,49 & 0,32 & $1,69 * *$ \\
\hline Depersonalizacija & 1 & 2 & 1,23 & 0,23 & $\mathbf{2 , 2 4 * *}$ \\
\hline Nezadovoljstvo osobnim postignućem & 1 & 2,83 & 1,51 & 0,40 & $1,81 * *$ \\
\hline Emocionalna iscrpljenost & 1 & 3,56 & 1,72 & 0,49 & $1,48 *$ \\
\hline Mogućnost kontrole na poslu & 1 & 4 & 2,88 & 062 & 1,11 \\
\hline Percipirana socijalna podrška & 2 & 4 & 3,25 & 0,67 & 1,31 \\
\hline
\end{tabular}

Legenda: Kolmogorov-Smirnov Test - *značajan uz p < 0,05; * značajan uz p $<0,01$

$\mathrm{Na}$ osnovu dobivenih aritmetičkih sredina (Tablica 3.) vidljivo je da, od tri supskale emocionalne inteligencije, najveći rezultat odgajateljice ostvaruju na skali izražavanja i imenovanja emocija te na skali sposobnosti upravljanja emocijama. Također se može uočiti da su za sve tri supskale, kao i za generalnu emocionalnu kompetenciju, aritmetičke sredine poprilično visoke, odnosno kreću se između vrijednosti 3 i 4 na skali čiji je raspon od 1 do 5, pri čemu 1 znači „uopće ne“, a 5 „u potpunosti da“. Na osnovi toga može se pretpostaviti da postoji tendencija procjene odgajateljica prema višim vrijednostima (negativno asimetrična krivulja), što može ukazivati na visoku razinu emocionalne kompetencije kod odgajateljica, no također može biti produkt namjernog ili nenamjernog boljeg prikazivanja sebe u svrhu obmane sebe ili drugih. 
Od tri faktora sagorijevanja, najnaglašenija je emocionalna iscrpljenost. $\mathrm{Na}$ osnovi rezultata ovog istraživanja, teško je govoriti koja je zapravo razina stresa kod ispitivanih odgajatelja, jer ne postoje norme koje bi omogućile takvo zaključivanje. Prosječni rezultati na sve tri supskale sagorijevanja kreću se između vrijednosti 1 i 2 na skali raspona od 1 do 4 (gdje 1 znači „uopće nije točno“, a 4 „potpuno točno“), što ukazuje na nizak i umjeren doživljaj sagorijevanja u radu odgajateljica.

Potom su izračunate interkorelacije između supskala emocionalne kompetencije, između supskala skale doživljaja sagorijevanja u radu te između skala nekih karakteristika posla (percipirane socijalne podrške i skale mogućnosti kontrole na poslu) (Tablica 3.).

Tablica 3. Interkorelacije generalne emocionalne kompetencije (GEK) te pripadnih supskala te interkorelacije generalnog doživljaja sagorijevanja u radu (GOS) i pripadnih supskala

\begin{tabular}{|c|c|c|c|c|}
\hline Skale & GEK & SURE & SIIE & SUE \\
\hline GEK & 1 &, $846 * *$ & ,849** &, $870 * *$ \\
\hline SURE & & 1 &, $543 * *$ &, $612 * *$ \\
\hline SIIE & & & 1 &, $636 * *$ \\
\hline SUE & & & & 1 \\
\hline Skale & GOS & D & NOP & EI \\
\hline GOS & 1 &, $604 \% *$ &, $864 * *$ & $913 * *$ \\
\hline $\mathrm{D}$ & & 1 &, $487 * *$ & $311 * *$ \\
\hline NOP & & & 1 & $665 *$ \\
\hline EI & & & & 1 \\
\hline
\end{tabular}

Legenda: generalna emocionalna kompetencija (GEK), sposobnost uočavanja i razumijevanja emocija (SURE), sposobnost izražavanja i imenovanja emocija (SIIE), sposobnost upravljanja emocijama (SUE); generalni doživljaj sagorijevanja u radu (GOS), emocionalna iscrpljenost (EI), nezadovoljstvo osobnim postignućem (NOP), depersonalizacija (D)

Značajnost **p $<0.01$

Najveću korelaciju s rezultatima na skali generalne emocionalne kompetencije ima supskala upravljanja emocija, potom supskala izražavanja i imenovanja emocija te zatim skala uočavanja i razumijevanja emocija (Tablica 3.). Na osnovi rezultata istraživanja može se zaključiti da su regulacija i upravljanje emocijama i impulsima, osobito onim neugodnima, u najvećoj mjeri povezani s emocionalnom kompetentnošću pojedinca. Sve supskale su značajno visoko povezane s generalnom emocionalnom kompetencijom, kao i međusobno (između 0,54 do 0,64 ), što je u prosjeku nešto viša povezanost u odnosu na povezanosti supskala između 0,35 i 0,51 (Takšić, 2006). Međutim, konstataciju o određenim razlikama u visini korelacija moramo uzeti s oprezom, jer su korelacije mjera koja je vrlo osjetljiva na broju ispitanika u određenom istraživanju. U oba slučaja, podatak da su pojedini aspekti emocionalne kompetencije pozitivno međusobno povezani, ukazuje na očekivanu činjenicu da je riječ o različitim aspektima istog konstrukta. Međutim, moguće je i da je veća povezanost između rezultata u supskalama emocionalne kompetencije u našem istraživanju ishod relativno homogenog uzorka odgajateljica, dok je u referentnom istraživanju (Takšić, 2006) istraživan slučajni uzorak ispitanika, različitih vrsta zanimanja. 


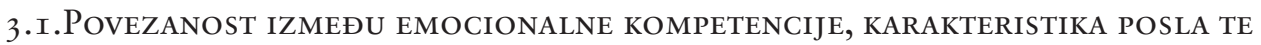 DOŽIVLJAJA SAGORIJEVANJA U RADU KOD ODGAJATELJICA}

Potom smo izračunali kanoničke korelacije između dimenzija: emocionalne kompetencije i doživljaja sagorijevanja u radu; karakteristika posla i emocionalne kompetencije te doživljaja sagorijevanja u radu i karakteristika posla. Međutim, utvrđene su i univarijatne unakrsne korelacije između pojedinih skala (dimenzija) svakog para karakteristika.

\section{I.I. Povezanost izmeĐu emocionalne kompetencije te doživljaja SAGORIJEVANJA U RADU KOD ODGAJATELJICA}

Tablica 4. Kanonička korelacijska analiza - povezanost dimenzija: emocionalne kompetencije s doživljajem sagorijevanja u radu; emocionalne kompetencije i nekih karakteristika posla; nekih karakteristika posla s doživljajem sagorijevanja u radu

\begin{tabular}{|c|c|c|c|c|}
\hline $\begin{array}{c}\text { Kanonička } \\
\text { korelacija }\end{array}$ & $\begin{array}{c}\text { Kvadrat } \\
\text { kanoničke korelacije }\end{array}$ & $\mathbf{H i}^{2}$-test & $\begin{array}{c}\text { Stupnjevi } \\
\text { slobode }\end{array}$ & Povezanost skupova varijabli \\
\hline 0,284 & 0,081 & 10,923 & 9 & $\begin{array}{c}\text { emocionalna kompetencija - } \\
\text { doživljaj sagorijevanja u radu }\end{array}$ \\
\hline 0,300 & 0,090 & 11,610 & 6 & $\begin{array}{c}\text { emocionalna kompetencija - neke } \\
\text { karakteristike posla }\end{array}$ \\
\hline 0,401 & 0,161 & $\mathbf{1 7 , 5 1 3 * *}$ & $\mathbf{6}$ & $\begin{array}{c}\text { doživljaj sagorijevanja u radu- } \\
\text { neke karakteristike posla }\end{array}$ \\
\hline
\end{tabular}

Legenda: ${ }^{*} \mathrm{p}<0.01$

Dobiveni rezultati kanoničke korelacijske analize ukazuju na unaprijed očekivanu statistički značajnu povezanost jedino između skupa varijabli doživljaja sagorijevanja u radu i skupa varijabli nekih karakteristika posla. Prvi kanonički korijen je statistički značajan, a korelacije pojedinih varijabli s prvim kanoničkim korijenom su visoke za sve varijable: emocionalnu iscrpljenost, depersonalizaciju, nezadovoljstvo osobnim postignućem (varijable sagorijevanja u radu), percipiranu socijalnu podršku i mogućnost kontrole na poslu (osobine posla) (Tablica 5.).

Tablica 5. Korelacije skupova varijabli s prvim kanoničkim korijenom (varijable: doživljaj sagorijevanja u radu te neke karakteristike posla)

\begin{tabular}{|c|c|}
\hline Varijable & Korijen $\mathbf{1}$ \\
\hline emocionalna iscrpljenost & 0,727 \\
\hline nezadovoljstvo osobnim postignućem & 0,898 \\
\hline depersonalizacija & 0,788 \\
\hline percipirana socijalna podrška & $-0,788$ \\
\hline mogućnost kontrole na poslu & $-0,811$ \\
\hline
\end{tabular}

Bold - neke osobine posla 
Potom smo istražili povezanosti između pojedinačnih supskala sve tri skupine varijabli, izračunali smo unakrsne korelacije između rezultata dobivenih na tim supskalama (dimenzijama) (Tablica 6.).

Tablica 6. Univarijatne unakrsne povezanosti: emocionalne kompetencije s doživljajem sagorijevanja u radu; emocionalne kompetencije i nekih karakteristika posla; nekih karakteristika posla s doživljajem sagorijevanja u radu

\begin{tabular}{|c|c|c|c|c|c|}
\hline Supskale & D & NOP & EI & SP & KP \\
\hline SURE & -.095 & .091 & .038 & .074 & $.208 *$ \\
\hline SIIE & $-.241 *$ & -.059 & -.136 & .143 & $.285 *$ \\
\hline SUE & -.119 & .060 & -.004 & $.197 *$ & $.203 *$ \\
\hline D & 1 & & & $-.218 *$ & $-.247 *$ \\
\hline NOP & & 1 & & $-.268 * *$ & $-.310 * *$ \\
\hline EI & & & 1 & $-.274 * *$ & $-.233 * *$ \\
\hline SP & & & & 1 & $.278 *$ \\
\hline KP & & & & & 1 \\
\hline
\end{tabular}

$* \mathrm{p}<0.05 *$ * $\mathrm{p}<0.01$

Legenda: sposobnost uočavanja i razumijevanja emocija (SURE), sposobnost izražavanja i imenovanja emocija (SIIE), sposobnost upravljanja emocijama (SUE); emocionalna iscrpljenost (EI), nezadovoljstvo osobnim postignućem (NOP), depersonalizacija (D); percipirana socijalna podrška (SP); mogućnosti kontrole na poslu (KP)

Od svih supskala generalne emocionalne kompetencije i doživljaja sagorijevanja jedino su značajno negativno povezane supskala depersonalizacije i supskala sposobnosti izražavanja i imenovanja emocija. Što je pojedinac sposobniji izražavati i imenovati emocije, osjećaj depersonalizacije će biti manji.

\section{RASPRAVA}

Glavni nalaz istraživanja ukazuje da su sve pronađene statistički značajne povezanosti između emocionalne kompetencije (s jedne strane) i obilježja vezanih uz posao - doživljaja sagorijevanja u radu te karakteristika posla (s druge strane) zapravo vrlo niske. Nije pronađena statistički značajna povezanost između emocionalne kompetencije i doživljaja sagorijevanja u radu, kao ni između emocionalne kompetencije i nekih karakteristika posla (percipirane socijalne podrške i mogućnosti kontrole na poslu). Statistički značajna povezanost pronađena je između doživljaja sagorijevanja u radu i nekih karakteristika posla (percipirane socijalne podrške i mogućnosti kontrole na poslu).

Općenito odgajateljice u prosjeku percipiraju umjereno visok stupanj kontrole na poslu $(2,88)$, kao i visoku socijalnu podršku na poslu $(3,25)$. U istraživanju o stresu psihologa i menadžera, koristeći isti upitnik ispitivanja percepcije i doživljaja posla, na skali generalnog doživljaja sagorijevanja na poslu, kao i na skalama depersonalizacije, nezadovoljstva osobnim postignućem i emocionalne iscrpljenosti, psiholozi su postigli više prosječne rezultate, u odnosu na menadžere (Bašić, 1999). Međutim, poslovi svih navedenih zanimanja (psihologa, menadžera, odgajateljica, sadrže interakcije velikog broja stresora, pa direktna usporedba rezultata nema previše smisla. 
Unutar supskala doživljaja sagorijevanja u radu, najveću povezanost s generalnim doživljajem sagorijevanja ima supskala emocionalne iscrpljenosti (Tablica 3.). Emocionalna iscrpljenost navodi se kao središnji fenomen doživljaja sagorijevanja kod pojedinaca u profesijama koje se bave ljudima (Francis i sur., 2004). Sagorijevanje je obilježeno tjelesnim i emocionalnim indikatorima, s predispozicijom da se ne uspije, da se istroši ili postane iscrpljen ukoliko se sebi postavlja prevelike energetske zahtjeve. Emocionalna iscrpljenost je središnji simptom sagorijevanja i njena povezanost s ostalim dimenzijama sagorijevanja je također visoka (Kalliath, 2001). Uslijed emocionalne iscrpljenosti dolazi do depersonalizacije, koja djelomično dovodi do smanjenog osobnog postignuća. Drugi autori smatraju da je depersonalizacija obrambeni odgovor na emocionalnu iscrpljenost, kad ostali obrambeni resursi nisu dostupni (Lee i Ashforth, 1990; Leiter, 1990; sve prema Kalliath i Beck, 2001). Depersonalizacija proizlazi iz emocionalne iscrpljenosti tako da se kod osobe koja radi u profesiji pomagača ljudima razvija distanciran, „bešćutan“ stav prema ljudima za koje bi se trebala brinuti. Ovakav stav induciran je kao posljedica potrošenih resursa i nedostatka energije profesionalnog pomagača ljudima. Nadalje, profesionalni pomagač razvija i negativna osjećanja koja su usmjerena i na samog sebe. Osjeća da trud koji ulaže ne uspijeva proizvesti pozitivne rezultate, pa se tako prestaje truditi (Maslach, 1982; prema Kalliath i Beck, 2001). Najnižu povezanost (premda svejedno značajnu i visoku) s rezultatima na generalnoj skali doživljaja sagorijevanja ima skala depersonalizacije. Razmatrajući povezanost svih supskala zajedno, najmanje su međusobno povezani rezultati na skali emocionalne iscrpljenosti i na skali depersonalizacije. Naime, moguće je da, primjerice, ranije razvijanje mehanizma depersonalizacije donekle može sačuvati pojedinca od emocionalnog iscrpljivanja.

Povezanost između socijalne podrške i osjećaja kontrole na poslu je statistički značajna i pozitivna (premda niska). Navedena povezanost može se objasniti potencijalnom mogućnošću da odgajateljice koje imaju podršku od svojih nadređenih i kolega, vjerojatnije istovremeno imaju i veću slobodu pri donošenju različitih odluka vezanih uz svoj posao. Također je moguće da su odgajatelji koji percipiraju da mogu samostalnije odlučivati u svom poslu i zadovoljniji poslom, pa su posljedično i cijelu radnu okolinu i pojedince skloniji percipirati pozitivnije (prepoznajući poželjne strane te okoline). Takav stav može rezultirati i pozitivnijim stavovima prema radnom okruženju, što kod suradnika može izazvati i pozitivne emocije, odnosno stavove prema njima samima. A to je, zapravo, socijalna podrška koju doživljavaju. Nadalje, odgajateljice koje smatraju da imaju veću kontrolu na poslu mogu procijeniti da im je vlastita inicijativa i omogućena zbog toga što se njihov trud cijeni i da su prepoznate njihove sposobnosti (stoga možda i percipiraju da imaju veću socijalnu podršku).

Što se tiče odnosa socijalne podrške i sagorijevanja na radu, dobiveni rezultati su u skladu s prethodnim rezultatima: većina istraživanja ukazuje na važnost socijalne podrške u fenomenu doživljaja sagorijevanja u radu, pri čemu pojedinci koji percipiraju veću podršku od strane nadređenih i kolega imaju i nižu razinu doživljaja sagorijevanja u radu (Kaliath i Beck, 2001). Također, socijalni radnici koji iskazuju znakove sagorijevanja imaju veći izostanak podrške kolega te lošiji odnos s kolegama u timu u odnosu na one koji ne iskazuju znakove sagorijevanja. Imaju manju mogućnost izražavanja vlastite kreativnosti, lošiju organizaciju unutar ureda, rade poslove koji ne spadaju u opis radnog mjesta $\mathrm{i}$ nemaju mogućnost profesionalnog usavršavanja (Friščić, 2006). U drugom istraživanju, veći psihološki zahtjevi i manja mogućnost kontrole na poslu značili su i veći doživljaj sagorijevanja (Demerouti i sur., 2001). 
U pogledu relacije emocionalne kompetencije i sagorijevanja na poslu, dobiveni rezultat nije u skladu s očekivanjima, kao niti s podacima iz literature u kojoj se navodi da se emocionalno kompetentniji pojedinci bolje nose sa stresom, te je tako i manja mogućnost doživljaja sagorijevanja u radu (Knežević i sur., 2005; Ciarrochi i sur., 2005). Primjerice, emocionalno kompetentni pojedinci usvajaju adaptivnije strategije suočavanja sa stresom (Campbell i Ntobedzi, 2007). Sposobnost upravljanja emocijama (kao komponenta emocionalne kompetencije) podrazumijeva mogućnost umanjivanja posljedica stresa i pronalaženje uspješnih strategija suočavanja sa stresom, što smanjuje vjerojatnost doživljaja sagorijevanja u radu. S obzirom na to da emocionalno kompetentni pojedinci pokazuju veće samopouzdanje (Goleman, 1998) realnije procjenjujući svoje mogućnosti, manja je mogućnost emocionalnog iscrpljivanja kao osnovne komponente doživljaja sagorijevanja u radu. Nezadovoljstvo osobnim postignućem pak proizlazi i iz razmišljanja da je trud koji osoba ulaže neefektivan (Kaliath i Beck, 2001) ili je osobna kompetencija niska (Burke, 2002; Kaliath i Beck, 2001). Emocionalno kompetentne osobe su svjesne vlastite kompetencije i ne sumnjaju u sebe, pa je manja vjerojatnost osjećaja smanjenog osobnog postignuća. Emocionalno kompetentne osobe bolje se nose sa stresom i kanaliziraju ga na konstruktivniji način u odnosu na one manje emocionalno kompetentne (Ciarrochi i sur., 2000). Stoga smo očekivali statistički značajnu negativnu povezanost između ova dva skupa varijabli.

Ljudi koji su sposobni imenovati i izraziti svoje emocije na način koji će im omogućiti da razriješe konflikte s okolinom na prihvatljiv način, vjerojatno će imati manju potrebu mentalno se distancirati i imati negativne stavove prema okolini. Imenovanje i izražavanje emocija je sposobnost koja omogućuje osobi da raspravi s radnom okolinom o onome što je muči u radnoj okolini, što implicira veću vjerojatnost rješavanja sukoba, otpuštanja napetosti i smanjenja otuđenja kao elemenata depersonalizacije. Budući da depersonalizacija zapravo podrazumijeva otuđenje od drugih i od sebe, odnosno od vlastitih emocija, pojedinac ima manju sposobnost izraziti i imenovati emocije.

Analizira li se odnos tri dimenzije emocionalne kompetencije (sposobnost uočavanja i razumijevanja emocija, sposobnost izražavanja i imenovanja emocija i sposobnosti upravljanja emocija) i mogućnosti kontrole na poslu, sve tri dimenzije pokazuju statistički značajnu pozitivnu povezanost s percepcijom kontrole na poslu, pri čemu je najveća povezanost između kontrole na poslu i sposobnosti izražavanja i imenovanja emocija, zatim kontrole na poslu i sposobnosti uočavanja i razumijevanja emocija te neznatno manja između kontrole na poslu i sposobnosti upravljanja emocijama

Jedno od mogućih objašnjenja za dobiveni rezultat je da pojedinci koji mogu precizno izraziti vlastite emocije i potrebe stvaraju sebi i više prilika za efikasno djelovanje i donošenje odluka, što može rezultirati i većom percepcijom kontrole na poslu. Osoba koja u većoj mjeri razumije vlastite emocije i u stanju je njima efikasno upravljati, sklonija je preuzimati vlastitu odgovornost u odnosu na one koji to ne mogu (Kirkcaldy i sur., 2008). Takva je osoba svjesna svoje „kreatorske“ uloge u vlastitom životu. Veća razina internalnosti daje osjećaj veće kontrole događanja u vlastitom životu, pa tako internalnija (emocionalno kompetentnija) osoba pokazuje i veću tendenciju za traženjem informacija. Traženje informacija sredstvo je za postizanje veće kontrole nad sobom i okolinom te nastoji usvajati i takve oblike ponašanja koji će joj to omogućiti.

Povezanost generalne emocionalne kompetencije sa socijalnom podrškom na poslu nije statistički značajna $(\mathrm{r}=0.160, \mathrm{p}>0.05)$, iako je smjer povezanosti pozitivan. Povezanost 
generalne emocionalne kompetencije $\mathrm{s}$ kontrolom na poslu je značajna i pozitivna $(\mathrm{r}=$ 0.272, p < 0.01): što je veća emocionalna kompetencija, veća je i mogućnost kontrole na poslu. Prema Golemanovoj $(1997,1998)$ teoriji emocionalnih kompetencija, pojedinac koji ima određene emocionalne kompetencije u većoj će mjeri prepoznavati prilike u kojima može imati utjecaja, stvarati prilike za ostvarivanje vlastitih ciljeva, vidjeti prepreke kao izazove, njegovati instrumentalne odnose te imati efektivne metode uvjeravanja, što stvara veći osjećaj kontrole u poslovnoj domeni. Emocionalno kompetentniji ljudi zadovoljniji su u situacijama mogućnosti manje kontrole na poslu od onih emocionalno nekompetentnijih koji favoriziraju visoku kontrolu na poslu. (Abraham, 2000). Visoka razina kontrole na poslu za ljude koji su pozicionirani nisko na dimenziji emocionalne kompetencije može biti „iracionalno“ definirana, odnosno, mogućnost kontrole na poslu za takve je pojedince uvijek niska jer imaju potrebu za stalnom kontrolom. Emocionalna kompetencija podrazumijeva i socijalnu kompetenciju, dakle, sposobnosti vezane uz stvaranje i održavanje dobrih odnosa s kolegama na poslu. Emocionalno kompetentniji pojedinci u većoj mjeri pružaju pomoć kolegama kad je potrebno, aktivno slušaju te održavaju otvorenu komunikaciju (Goleman, 1998). Navedeni atributi stvaraju kod kolega i nadređenih osjećaj da se na takve ljude može osloniti, što bi zauzvrat trebalo rezultirati većom socijalnom podrškom emocionalno kompetentnijim pojedincima.

Sa socijalnom podrškom na poslu, jedino je supskala sposobnosti upravljanja emocijama statistički značajno povezana s upravljanjem emocijama. Pojedinci koji su sposobni ublažavati neugodne i pojačavati ugodne emocije, bez umanjivanja ili prenaglašavanja informacija koje prenose te koji se mogu refleksivno uživjeti ili odvojiti od emocija, u većoj će mjeri imati socijalnu podršku na poslu.

Doživljaj sagorijevanja u radu značajno negativno korelira sa socijalnom podrškom i mogućnošću kontrole. Moguće je da pojedinac u početku rada (u ovom slučaju kao odgajateljica) ima manju socijalnu podršku i manju mogućnost kontrole na poslu, što dovodi do doživljaja stresa. U stanju kroničnog stresa, odnosno sagorijevanja u radu, mogućnost kontrole na poslu je još manja, a socijalna podrška izostaje u još većoj mjeri ili je pojedinac jednostavno nije u stanju percipirati. Sve tri supskale sagorijevanja u radu značajno su negativno povezane s percipiranom socijalnom podrškom. Dakle, što osoba ima manju socijalnu podršku na poslu, to će imati bezosjećajniji i ravnodušniji odnos prema osobama na poslu, odnosno, bit će neosjetljivija i neprilagođenijeg ponašanja, kao i nezadovoljnija osobnim postignućima te emocionalno iscrpljenija. Moguće objašnjenje za povezanost depersonalizacije i socijalne podrške leži u tome da, što je osoba više depersonalizirana, u manjoj će mjeri percipirati socijalnu podršku, što je vjerojatno posljedica njene otuđenosti od drugih. Osjećaj kontrole na poslu je također značajno negativno povezan sa sve tri supskale doživljaja sagorijevanja u radu: što je osjećaj kontrole na poslu manji, osoba će imati osjećaj manjeg osobnog postignuća i manji osjećaj kompetencije, pa će biti emocionalno iscrpljenija i sklonija depersonalizaciji. Osobe nezadovoljne osobnim postignućem doživljavaju trajni osjećaj da njihov uloženi trud ne daje pozitivne rezultate pa se prestaju truditi. Ovo odustajanje i nemogućnost nošenja sa situacijom na poslu stvara manji osjećaj kontrole.

Nedostaci istraživanja sastoje se u činjenici da su na rezultate mogli biti djelomično utjecati i premali broj ispitanika u istraživanju, ali i socijalno poželjno odgovaranje na pitanja iz upitnika. S druge strane, stav prema radu te izgaranje na poslu može direktno (i neslučajno) ovisiti i o stilu vodstva u pojedinoj ustanovi, pa je ovisno o tome moglo 
doći do određene distorzije dobivenih rezultata. Socijalno poželjni odgovori, bez obzira na anonimnost i znanstvenu svrhu istraživanja, mogu biti uvjetovani percepcijom mogućnosti da se njihovi odgovori na pitanja mogu reflektirati na njihov radni status te stav rukovoditelja prema njima. S druge strane, socijalno poželjni odgovori mogu direktno odražavati realnu samopercepciju ispitanika (neki ljudi jednostavno sebe percipiraju u društveno poželjnom „svjetlu“). U prilog ovom tumačenju govori i činjenica da je i dobivena premala varijabilnost rezultata na skali doživljaja sagorijevanja u radu, gdje su rezultati uglavnom niski, te na skali emocionalne kompetencije na kojoj su rezultati uglavnom visoki. Dodatni nedostatak istraživanja može biti činjenica da rezultate povezane s varijablama sagorijevanja na poslu treba uzeti oprezno, zbog distribucija rezultata koje statistički značajno odstupaju od Gaussove raspodjele.

U budućim istraživanjima trebalo bi se usmjeriti na traženje drugih varijabli koje pridonose doživljaju stresa, odnosno sagorijevanju u radu, a koje ovim istraživanjem nisu bile obuhvaćene, kao npr. osobine ličnosti, zahtjevi posla i sl. Poželjno bi bilo primijeniti kontrolne ljestvice, kako bismo i na taj način bili sigurniji u vjerodostojnost dobivenih podataka. Nadalje, u slučaju težnje osmišljavanja nacrta primijenjenog istraživanja na manjem broju ispitanica, pogodno bi bilo odabrati sudionice odabrati iz istog dječjeg vrtića ili iz različitih vrtića u kojima bi sudionice bile ujednačene po relevantnim čimbenicima (stil vodstva, organizacijska klima). U slučaju longitudinalnog istraživanja djelovanja varijabli emocionalne kompetencije i percepcije stresa vezanog za radno mjesto odgajateljica na profesionalno sagorijevanje omogućio bi se jasniji uvid u ovu povezanost. A takav bi uvid ukazao i na eventualno promijenjene oblike i smjernice rada psihologa s odgajateljima, vezane uz razvoj njihove emocionalne kompetencije. To je osobito bitno u situacijama specifičnih stresnih događaja vezanih za ulogu odgajatelja (preopterećenost, konflikti i sl.) i pri diferencijalnom suzbijanju pojedinih komponenti sindroma profesionalnog sagorijevanja.

Pravodobnim intervencijama vezanima uz doživljaj stresa na poslu mogli bi se smanjiti njegovi negativni efekti u području fizioloških parametara (i posljedično, smanjiti bolovanja i zamjene), ali u pogledu radnog učinka (prevencija nekvalitetnog rada). U odnosu na specifičnost odgajateljskog poziva u kojem je, između ostalog, važan emocionalni odnos s djecom i zadovoljenje njihovih potreba, može se očekivati da njihova stalna izloženost stresorima može umanjiti uspješnost odgajateljskog posla, bez obzira što njihov doživljaj stresa može varirati.

\section{ZAKLJUČAK}

Nije pronađena povezanost između emocionalne kompetencije i doživljaja sagorijevanja u radu. Nije pronađena niti povezanost između emocionalne kompetencije i nekih karakteristika posla (percipirane socijalne podrške i mogućnosti kontrole na poslu). Međutim, pronašli smo statistički značajnu univarijatnu pozitivnu povezanost između svih dimenzija emocionalne kompetencije i mogućnosti kontrole na poslu. Postoji povezanost između doživljaja sagorijevanja u radu i nekih karakteristika posla (percipirane socijalne podrške i mogućnosti kontrole na poslu). Ali ključno je napomenuti da su sve pronađene statistički značajne povezanosti zapravo vrlo niske. 
Rezultati istraživanja ukazuju da je u pokušaju uspješnog suočavanja sa stresom te izbjegavanja doživljaja sagorijevanja u radu važna percepcija podrške od strane kolega i nadređenih, kao i mogućnost kontrole na poslu. Emocionalna kompetencija nije se pokazala značajno povezana s doživljajem sagorijevanja na poslu. Nepovezanost emocionalne kompetencije i doživljaja sagorijevanja u radu može ukazivati na činjenicu da je emocionalna kompetencija samo jedan od brojnih čimbenika koji mogu utjecati na doživljaj sagorijevanja. Međutim, moguće je da je nepovezanost emocionalne kompetencije i doživljaja sagorijevanja na poslu djelomično pod utjecajem metodoloških nedostataka istraživanja: malog broja ispitanika ili namjernog ili nenamjernog iskrivljavanja rezultata od strane ispitanika.

\section{LITERATURA}

Abraham, R. (2000) The Role of Job Control as a Moderator of Emotional Dissonance and Emotional Intelligence-Outcome Relationship, Journal of Psychology, god. 134, sv. 2, str. 169-184.

Ajduković, M. (1996) Sindrom sagorijevanja na poslu. U: Ajduković, M., Ajduković, D. (ur.), Pomoć i samopomoć u skrbi za mentalno zdravlje pomagača, Zagreb, Društvo za psihološku pomoć, str. 21-27.

Auerbach, M.S., Gramling, E.S. (1998) Stress Managment, Psychological Foundations, New Jersey, Prenticehall, Inc.

Bašić, A. (1999) Percepcija psiholoških karakteristika posla i doživljaj sagorijevanja u radu, Diplomski rad, Zagreb, Sveučilište u Zagrebu, Filozofski fakultet.

Boyle, G.J., Borg, M.G., Falzon, J.M., Baglioni, A.J. (1995) A structural model of the dimensions of teachers stress, British Journal of Educational psychology, god. 65, sv.1, str. 49-67.

Burke, R.J. (2002) Work experiences and psychological wellbeing of former hospital based nurses, Psychological Reports, god. 91, sv. 3, str. 1059-1064.

Campbell, A., Ntobedzi, A. (2007) Emotional Intelligence, Coping and Psychological Distress: A Partial Least Squares Approach to Developing a Predictive Model, Electronic Journal of Applied Psychology; god. 3, sv. 1, str. 39-54.

Ciarrochi, J., Deane, F.P., Anderson, S. (2000) Emotional intelligence moderates the relationship between stress and mental health, Wollongong, Australia, University of Wollongong.

Demerouti, E., Bakker, A.B., Jonge, J., Jenssen, P., Schaufeli, W.B. (2001) Burnout an engagement at work as a function of demands and control. Scandinavian Journal of Work Environmental Health, god. 27, sv. 4, str. 279-286.

Friščić, Lj. (2006) Čimbenici profesionalnog stresa i sagorijevanja u radu socijalnih radnika u Centru za socijalnu skrb, Zagreb, Centar za socijalnu skrb Zagreb.

Goleman, D. (1997) Emocionalna inteligencija, Zagreb, Mozaik knjiga.

Goleman, D. (1998) Working with Emotional Intelligence, New York, Bantam Books. 
Jayan, C. (2006) Emotional Competence, Personality and Job Attitudes as Predictors of Job Performance, Journal of Indian Academy of Applied Psychology. god. 32, sv. 2, str. 135-144.

Jordan, P.J., Ashtanasy, N.M, Heitel, C.E., (2002) Emotional Intelligence as a Moderator of Emotional and Behavoral Reactions to Job Insecurity, Academy of Menagment Review, god. 273, str. 361-372.

Francis, L.J., Kaldor, P., Shevlin, M., Lewis, C.A. (2004) Assessing- Emotional Exhaustion Among the Australian Clergy: Internal Reliability and Construct Validity of the Scale of Emotional Exhaustion in Ministry, Review of Religious Research, god. 45, sv. 3., str. 269-277.

Friedman, I.A. (2000) Burnout in teachers: Shattered dreams of impeccable professional performance, Journal of Clinical Psychology, god. 56, sv. 5, str. 595-606.

Furr, R.M. (2005) Differentiating happiness and self-esteem, Individual differences research, god. 3, str. 105-127.

Humpel, N., Caputi, P., Math, G.D. (2001) Exploring the relationship between work stress, years of experiance and emotional competency using a sample of Australian mental health nurses, Journal of Psychiatric and Mental Health nursing, god. 8, sv. 5, str. 399-403.

Kaliath, T.J, Beck, A. (2001) Is the path to burnout and turnover paved by a lack of supervisory support? A structural equations test, New Zealand Journal of Psychology, god. 30, sv. 2, str. 72-78.

Kelly, A.L., Berthelsen, D.C. (1997) Teachers coping with change: The stories of two preschool teachers, Australian Research in Early Childhood Education, sv. 1, str. 62-70.

Kirkcaldy, B. D., Cooper, C. L., Furnham, A.F. (1998) The relationship between type a, internality-externality, emotional distress and perceived health, Personality and Individual Differences, god. 26, sv. 2, str. 223-235.

Kyriacou, C. (1981) Social support and occupational stress among school teachers, Educational Studies, god. 1, sv. 7, str. 55-60.

Lopez, P. N., Salovey, P., Straus, R. (2003) Emotional intelligence, personality, and the perceived quality of social relationship, Personality and Individual Differences, god. 35, str. 641-658.

Mayer, J.D., Salovey, P. (1990) Emotional intelligence, Imagination, Cognition and Personality, god. 9, str. 185-211.

Maslach, C., Jackson, S. (1981) The Maslach Burnout Inventory, Palo Alto, CA, Consulting Psychologists Press.

Nunnally, J. C. (1978) Psychometric theory, New York, McGraw-Hill.

Petz, B. (2002) Osnovne statističke metode za nematematičare, Jastrebarsko: Naklada Slap.

Roberts, R.D., Zeidner, M., Matthews, G. (2001) Does Emotional Intelligence Meet Traditional Standards for an Intelligence? Some New Data and Conclusions, Emotion, god. 1, sv. 3, str. 196-231. 
Salovey, P., Mayer, J.D. (1990) Emotional intelligence, Imagination, Cognition and Personality, god. 9, str. 185-211.

Sauter, S., Hurrell, J., Murphy, L., Levi, L. (1997) Psychosocial and organizational factors. U: Stellman, J. (ur.), Encyclopaedia of Occupational Health and Safety, sv. 1, Geneva, Switzerland, International Labour Office, str. 1-34.

Schutte, N.S., Malouff, J.M., Hall, L.E., Haggerty, D.J., Cooper, J.T., Golden, C.J. (1998) Development and validation of a measure of emotional intelligence, Personality and Individual Differences, god.. 25, str. 167-177.

Takšić, V. (1998) Validacija konstrukta emocionalne inteligencije, Neobjavljena doktorska disertacija, Zagreb, Filozofski fakultet Sveučilišta u Zagrebu.

Takšić, V. (2002) Upitnici emocionalne inteligencije (kompetentnosti), U: K. Lackovi\}Grgin, A. Bautović, V. Ćubela i Z. Penezić (ur.), Zbirka psihologijskih skala i upitnika (str. 27-45), Zadar, Filozofski fakultet u Zadru.

Takšić, V., Mohorić, T., Munjas, R. (2006) Emocionalna inteligencija: teorija, operacionalizacija, primjena $\mathrm{i}$ povezanost $\mathrm{s}$ pozitivnog psihologijom, Društvena istraživanja, sv. 4-5, str. 729-752.

Slalski, M., Cartwright, S. (2003) Emotional Intelligence Training and its Implications for Stress, Health and Performance, Stress and Health, god. 19, sv. 4, str. 233-239.

Škrinjar, J. (1994) Profesionalna opterećenost i sindrom burnout djelatnika u ustanovama za rehabilitaciju osoba s težom mentalnom retardacijom, Disertacija, Zagreb, Fakultet za defektologiju Sveučilišta u Zagrebu.

Živčić-Bećirević, I., Smojver- Ažić, S. (2005) Izvori stresa na poslu odgajatelja u dječjim vrtićima, Psihologijske teme, god. 14, sv. 2, str. 3-13.

\section{The Relationship between the Experience of Job Burn-Out, Emotional Competence and Job Characteristics of Preschool Children's Teachers}

\section{SUMMARY}

The aim of the study was to find a correlation between work burnout, emotional competence and two job characteristics: social support at work and ability of control at work. We have examined a sample of 112 female preschool teachers from four kindergartens in Zagreb. We have tried to determine the correlation: among work burnout and emotional competence; among emotional competence and two job characteristics (social support at work and ability of control at work); among work burnout and two job characteristics. We have used instruments: a Questionnaire for testing the perception and experience of work and Emotional competence questionnaire UEK45. The results showed no statistically significant correlations between emotional competence and experience burnout at work, as well as between emotional competence and some job characteristics (perceived social support and the ability of control on the work). We have found a statistically significant positive correlation between experience of work burnout and two job characteristics. However, it is crucial to note that they all found statistically significant correlations are actually very low.

KEY WORDS: educators, the ability to control at work, social support, relationship 
